\title{
UPAYA MENINGKATKAN AKTIVITAS HASIL BELAJAR SISWA PADA MATERI PECAHAN DENGAN PENDEKATAN CONTEXTUAL TEACHING AND LEARNING KELAS IV SDN SUMUR 03
}

\section{Pukjiwati $\bowtie$}

SD Negeri Sumur 03 Cluwak Pati

Jawa Tengah, Indonesia

\section{Info Artikel Abstract}

Sejarah Artikel:

Diterima Desember 2016

Disetujui April 2017

Dipublikasikan Juni 2017

Keywords:

Actiivty,

learning outcomes,

fractions, CTL
The purpose of this study was to determine whether there is a science learning outcomes in Operation Count Fraction In Problem Solving in Elementary school fourth grade Sumur 03, Subdistrict Cluwak, Pati. In the first semester of the school year 2016/2017 This research is a classroom action research to solve the problem of whether the approach CTL can improve student learning outcomes. PTK lasted until 2 cycles, each cycle consisting of (1) planning, (2) actions, (3) of observation, and (4) reflection. The fourth connection is regarded as one cycle. Collection and use of technical documentation, observation and testing, data collection tools such as document journal learning, observation sheets and test items. Data analysis using descriptive comparative by comparing baseline data of the first cycle and the second cycle data followed by reflection. The study of 18 students learning the standard minimum value of 65, which means that students who have reached a value above 65 otherwise been completed. Furthermore, students who achieve a value of less than or equal to 65 otherwise unresolved in learning and need to get improvements in learning. From the research results at the end of the lesson formative tests turned out of 18 students who achieve grades above completeness only 8 students, if diprosentase students who otherwise completed only $35 \%$. So unresolved reached $65 \%$. The conclusion of the research approach CTL can improve the quality of student learning outcomes of the Mathematics of Operations Troubleshooting Count Fraction in fourth grade elementary school Sumur 03, District Cluwak, Pati regency, through the medium of learning and teaching.

\begin{abstract}
Abstrak
Tujuan penelitian ini adalah untuk menentukan apakah ada hasil belajar ilmu pada Operasi Hitung Pecahan Dalam Pemecahan Masalah di kelas IV Sekolah Dasar Negeri Sumur 03, Kecamatan Cluwak, Pati. Pada semester I tahun pelajaran 2016/2017 Penelitian ini merupakan penelitian tindakan kelas untuk memecahkan masalah apakah pendekatan CTL dapat meningkatkan hasil belajar siswa. PTK berlangsung sampai 2 siklus, setiap siklus terdiri dari (1) perencanaan, (2) tindakan, (3) observasi atau pengamatan, dan (4) refleksi. Hubungan keempat dianggap sebagai satu siklus. Pengumpulan dan penggunaan dokumentasi teknis, observasi dan pengujian, alat pengumpulan data berupa dokumen pembelajaran jurnal, lembar observasi dan tes item. Analisis data menggunakan descriptive Komperatif dengan membandingkan baseline data siklus pertama dan data siklus kedua diikuti oleh refleksi. Hasil studi dari 18 siswa standar belajar minimum nilai 65 , yang berarti siswa yang telah mencapai nilai diatas 65 dinyatakan telah selesai. Selanjutnya, siswa yang mencapai nilai kurang atau sama dengan dari 65 dinyatakan belum terselesaikan dalam belajar dan perlu mendapatkan perbaikan dalam pembelajaran. Dari hasil penelitian pada akhir pelajaran tes formatif ternyata dari 18 siswa yang mencapai nilai di atas kelengkapan hanya 8 siswa, jika diprosentase siswa yang dinyatakan selesai hanya 35\%. Jadi yang belum terselesaikan mencapai 65\%. Kesimpulan dari penelitian pendekatan CTL ini dapat meningkatkan kualitas hasil belajar siswa terhadap mata pelajaran Matematika tentang Operasi Hitung Pecahan dalam Pemecahan Masalah kelas IV SD Negeri Sumur 03, Kecamatan Cluwak, Kabupaten Pati, melalui media belajar dan mengajar.
\end{abstract}

(C) 2017 Universitas Muria Kudus 


\section{PENDAHULUAN}

Upaya dalam mencerdaskan kehidupan bangsa dan mengembangkan kualitas manusia seutuhnya adalah misi pendidikan yang menjadt tanggung jawab professional setiap guru. Namun salah satu permasalahannya pendikan yang dihadapi oleh bangsa Indonesia adalah rendahnya mutu pendidikan pada setiap jenjang pendidikan, khususnya pendidikan dasar dan menengah. Berbagai usaha telah dilakukan untuk meningkatkan mutu pendidikan nasional, antara lain melalui berbagai pelatihan dan peningkatan kualifikasi guru, penyempurnaan kurikulum, pengadaan buku dan alat pelajaran, perbaikan sarana dan prasarana pendidikan lainnya, dan peningkatan mutu manajemen sekolah. Namun demikian, berbagai indikator mutu pendidikan belum menunjukan peningkatan yang merata.

Meskipun usaha-usaha yang telah dilakukan tersebut masih belum menghasilkan mutu pendidikan yang diharapkan, tetapi Pemerintah melalui Dinas Pendidikan Nasional tidak putus asa. Usaha-usaha ke arah peningkatan mutu pendidikan terus dilakukan dan berbagai terobosan baru terus diperkenalkan. Terobosan-terobosan terus dilakukan oleh Dinas Pendidikan Nasional, misalnya terobosan dalam pengelolaan sekolah; terobosan dalam peningkatan sumber daya tenaga kependidikan adalah melalui pelatihan terintegrasi bagi guru, kepala sekolah dan staf dinas; dan terobosan dalam pengembangan materi adalah dengan rintisan pengembangan pembelajaran pendekatan CTL.

Berbicara mengenai mutu pendidikan, maka kita tidak pernah lepas dengan proses belajar mengajar. Karena keberhasilan dalam proses belajar mengajar akan mempengaruhi mutu pendidikan. Namun proses belajar mengajar yang terjadi sekarang seringkali membuat kecewa, jika dikaitkan dengan pemahaman peserta didik terhadap materi ajar. Walaupun seringkali kita ketahui bahwa banyak yang mungkin mampu menyajikan tingkat pemahaman yang tidak baik terhadap materi yang diajarkan, tetapi pada kenyataannya mereka seringkali tidak memahami atau mengerti secara mendalam pengetahuan tersebut.

Sebagian besar dari peserta didik tidak mampu menghubungkan antara apa yang mereka pelajari dengan bagaimana pengetahuan tersebut akan dipergunakan atau dimanfaatkan. Peserta didik memiliki kesulitan untuk memahami konsep akademik sebagaimana mereka biasa diajarkan, yaitu menggunakan sesuatu yang abstrak dan metode ceramah, mereka juga butuh untuk memahami konsep-konsep yang berhubungkan dengan tempat kerja dan masyarakat dengan tempat kerja dan masyarakat pada umumnya dimana mereka akan hidup dan bekerja. Untuk itulah, dewasa ini guru tidak cukup hanya menyampaikan pengetahuan kepada peserta didik di kelas karena materi yang diperolehnya tidak selalu sesuai dengan perkembangan masyarakat. Yang dibutuhkannya adalah kemampuan untuk mendapatkan dan mengelola informasi yang sesuai dengan kebutuhan profesinya. Mengajar bukan lagi usaha untuk menyampaikan ilmu pengetahuan, melainkan juga usaha untuk menciptakan sistem lingkungan yang membelajarkan peserta didik agar tujuan pengajaran dapat tercapai secara optimal. Mengajar dalam pemahaman seperti ini memerlukan suatu strategi belajar mengajar sesuai. Mutu pengajaran tergantung pada pemilihan strategi yang tepat bagi tujuan yang hendak dicapai, terutama dalam upaya mengembangkan kreatifitas dan sikap inovasi peserta didik. Untuk itu perlu dibina dan dikembangkan kemampuan profesional guru untuk mengelola progam pengajaran dengan strategi belajar mengajar yang kaya dengan variasi. Pemakaian metode mengajar yang tepat akan dapat mengikis pendapat umum bahwa Matematika itu sulit. "Matematika bukanlah bidang studi yang sulit dipelajari asalkan strategi penyampaiannya cocok dengan kemampuan yang mempelajari". (Hudoyo, 1990 : 83). Pemilihan metode belajar yang tepat dan sesuai akan sangat menentukan keberhasilan dalam proses belajar mengajar.

Persoalannya sekarang adalah bagaimana menemukan cara yang terbaik untuk menyampaikan berbagai konsep yang diajarkan sehingga semua peserta didik dapat menggunakan dan mengingat lebih lama konsep tersebut. Bagaimana setiap individual mata pelajaran dipahami sebagai bagian yang saling berhubungan dan membentuk satu pemahaman yang utuh. Bagaimana seorang guru dapat berkomunikasi secara efektif dengan peserta didiknya yang selalu bertanya-tanya tentang alasan dari sesuatu yang berhubungan dari apa yang mereka pelajari. Bagaimana seorang guru dapat membuka wawasan berpikir yang beragam dari seluruh peserta didik, sehingga dapat membuka berbagai pintu kesempatan selama hidupnya. Hal ni merupakan tantangan yang dihadapi seorang guru setiap hari dan tantangan bagi pengembangan kurikulum.

Untuk dapat mencapai tujuan pembelajaran Matematika hendaknya diarahkan pada kegiatan-kegiatan yang mendorong peserta didik untuk belajar secara aktif baik secara mental, fisik maupun sosial. Dalam pembelajaran hendaknya mengutamakan keterlibatan indera, 
emosi, karsa, karya dan nalar peserta didik. Secara aktif untuk menemukan sendiri pengetahuan melalui interaksi dengan lingkungan. Guru berperan sebagai fasillitor dan motivator dalam mengoptimalkan peserta didik dalam belajar, untuk itu dalam merancang pembelajaran hendaknya memberikan kesempatan kepada peserta didik untuk belajar seluas-luasnya dan membangun pengetahuan sendiri.

Namun kenyataannya di lapangan, guru dalam mengajarkan Matematika tidak melibatkan indera, emosi, karsa, karya dan nalar peserta didik secara optimal. Guru berperan sebagai pusat belajar peserta didik dan lebih aktif dalam proses belajar mengajar, guru berusaha menjelaskan semua materi sejelas mungkin sedangkan peserta didik pasif menerima apa yang diberikan guru.

Di antara pokok bahasan Matematika yang diajarkan di sekolah pada jenjang SD, salah satunya adalah materi tentang Melakukan operasi hitung pecahan dalam pemecahan masalah. Pada materi ini peserta didik kadang sulit memahami konsepnya. Sehingga anak didik sulit untuk memecahkan masalah yang ada hubungannya dengan materi tersebut. Dari sinilah timbul masalah yang memerlukan jalan pemecahannya. Bagaimana seorang guru harus menggunakan metode, teknik, cara, atau model pembelajaran yang sesuai untuk mengajarkan materi tersebut. Sekarang ini telah banyak metode yang diterapkan dalam pembelajaran Matematika, misal: metode ceramah, metode tugas, metode ekspositori, dan lain-lain. Pada pembelajaran konvensional yang ada pada proses kegiatan belajar mengajarnya berpusat pada guru, guru hanya mentransfer ilmu pengetahuan yang dimiliki kepada peserta didik sehingga guru dianggap segalanya oleh peserta didik. Tetapi pada pembelajaran dengan pendekatan CTL guru mengajarkan materi yang ada dengan keadaan yang sebenarnya/kongkrit. Sehingga pembelajaran secara alamiah dalam bentuk siswa mengalami secara langsung sehingga pembelajaran lebih bermakna.

Dari uraian latar belakang dapat diidentifikasi sebagai masalah yang perlu dipecahkan. Identifikasi masalah yang dimaksud adalah penerapan pembelajaran pendekatan CTL dapat memberikan hasil positif terhadap prestasi belajar siswa pada mata pelajaran Matematika dengan materi pokok tentang Melakukan operasi hitung pecahan dalam pemecahan masalah, terungkap beberapa masalah yang terjadi dalam proses pembelajaran, yaitu :

a. Rendahnya tingkat penguasaan terhadap materi pembelajaran pada mata pelajaran
Matematika dengan tema/aspek "Melakukan operasi hitung pecahan dalam pemecahan masalah".

b. Penyampaian pembelajaran pada materi Melakukan operasi hitung pecahan dalam pemecahan masalah kurang memfungsikan alat peraga dalam penjelasan terhadap siswa.

c. Guru kurang memberi kesempatan siswa untuk bertanya tentang materi yang belum jelas.

d. Motivasi siswa terhadap pembelajaran Matematika kurang, sehingga siswa tidak merespon penjelasan guru.

e. Siswa kurang memperhatikan pembelajaran dengan baik

Mengingat luasnya ruang lingkup yang terkandung alam penelitian ini, maka kiranya perlu peneliti memberikan batasan sehingga ruang lingkupnya lebih jelas. Adapun batasan masalah dalam penelitian ini adalah sebagai berikut :

Tentang peningkatan aktifitas dan hasil belajar Matematika tentang Melakukan operasi hitung pecahan dalam pemecahan masalah melalui pendekatan CTL di kelas IV SD Negeri Sumur 03, Kecamatan Cluwak, Kabupaten Pati pada semester I Tahun Pelajaran 2016/2017?

Berdasarkan uraian di atas, maka rumusan masalah dalam penelitian ini adalah: "Bagaimana cara meningkatkan prestasi belajar siswa dengan menggunakan pendekatan CTL pada mata pelajaran Matematika dengan materi pokok Melakukan operasi hitung pecahan dalam pemecahan masalah di kelas IV Sekolah Dasar Negeri Sumur 03 Kecamatan Cluwak, tahun 2016/2017?

1. Apakah dengan pendekatan CTL dapat meningkatkan aktifitas belajar Matematika tentang Melakukan operasi hitung pecahan dalam pemecahan masalah kelas IV SD Negeri Sumur 03, Kecamatan Cluwak, Kabupaten Pati pada semester I tahun pelajaran 2016/2017?

2. Apakah dengan pendekatan CTL dapat meningkatkan hasil belajar Matematika tentang Melakukan operasi hitung pecahan dalam pemecahan masalah kelas IV SD Negeri Sumur 03, Kecamatan Cluwak, Kabupaten Pati pada semester I tahun pelajaran 2016/2017?

Tujuan yang ingin dicapai dalam penelitian ini adalah :

1. Untuk mengetahui seberapa besar peningkatan motivasi siswa dalam belajar Matematika tentang Melakukan operasi hitung pecahan dalam pemecahan masalah melalui pendekatan CTL 
2. Untuk mengetahui seberapa besar peningkatan hasil belajar siswa dalam belajar Matematika tentang Melakukan operasi hitung pecahan dalam pemecahan masalah melalui pendekatan CTL

Penelitian ini diharapkan memberikan manfaat :

a. Bagi Guru

Hasil penelitian ini dapat memberi masukan dalam upaya pemilihan model pembelajaran yang tepat, juga sebagai pedoman dalam melaksanakan pembelajaran dengan pendekatan CTL

b. Bagi Lembaga Pendidikan

Hasil penelitian ini dapat digunakan sebagai masukan dalam menetukan pola pengajaran di sekolah tersebut, dan juga sebagai pertimbangan dalam pelaksanaan pembelajaran dengan kurikulum KTSP serta Kurikulum 2013 yang sedang dipersiapkan pelaksanannnya dimasing-masing lembaga pendidikan khususnya pendidikan dasar.

c. Bagi Peserta Didik

Penerapan pembelajaran CTL yang dilaksanakan selama penelitian diharapkan menambah pengalaman belajar dan menumbuhkan karakter positif pada diri peserta didik, karena peserta didik terlibat secara langsung dalam proses belajar mengajar yang dihubungkan dengan dunia nyata anak sehingga konsep-konsep yang ditemukan akan lebih lama diingat dan dimengerti yang pada akhirnya siswa dapat mempergunakan konsep-konsep tersebut dalam kehidupan sehari-hari di tengah masyarakat.

d. Bagi Peneliti

Penelitian ini sebagai sarana untuk meningkatkan kemampuan menulis dan menyusun Penelitian Tindakan Kelas (PTK) serta dapat menambah pengetahuan dan ketrampilan dalam menyelenggarakan proses belajar mengajar khususnya pembelajaran dengan pendekatan CTL.

e. Manfaaf bagi Perpustakaan Sekolah.

Penelitian Tindakan Kelas (PTK) sebagai salah satu model pendekatan dan strategi dalam mengembangkan, meningkatkan prestasi belajar yang diaplikasikan berdaya guna di perpustakaan sekolah.

\section{Tinjauan Tentang Pendekatan dan Metode Dalam Pembelajaran}

CTL merupakan strategi yang melibatkan seswa secara penuh dalam proses pembelajarannya. Siswa didorong untuk beraktifitas mempelajari materi pelajaran sesuai dengan topik yang akan dipelajarinya. Belajar dalam konteks CTL adalah proses pengalaman secara langsung.

Contextual Teaching and Learning (CTL) adalah suatu strategi pembelajaran yang menekankan kepada proses keterlibatan siswa secara penh ntuk dapat menemukan materi yang dipelajari dan menghubungkannya dengan situasi kehidupan nyata sehingga mendorong siswa untuk dapat menerapkannya dalam kehidupan mereka. Ada tiga hal yang harus dipahami. Pertama CTL menekankan kepada proses keterlibatan siswa untuk menemukan materi, kedua CTL mendorong agar siswa dapat menemukan hubungan antara materi yang dipelajari dengan situasi kehidupan nyata, ketiga mendorong siswa untuk dapat menerapkan dalam kehidupan.

Terdapat lima karakteristik penting dalam proses pembelajaran yang menggunakan pendekatan CTL.

1. Pembelajaran merupakan proses pengaktifan pengetahuan yang sudah ada (activating knowledge)

2. Pembelajaran ntuk memperoleh dan menambah pengetahuan baru (acquiring knowledge)

3. Pemahaman pengetahuan (understanding knowledge)

4. Mempraktikan pengetrahuan dan pengalaman tersebut (applying knomledge)

5. Melakukan refleksi (reflecting knowledge)

CTL banyak dipengarhi oleh filsafat konstruktisme yang mulai digagas oleh Mark Baldwin dan selanjutnya dikembangkan oleh Jean Piaget. Piaget berpendapat, bahwa sejak kecil setiap anak sudah memiliki struktur kognitif yang kemudian dinamakan "skema". Skema terbentuk karena pengalaman, dan proses penyempurnaan skema itu dinamakan asimilasi dan semakin besar pertumbuhan anak maka skema akan semakin sempurna yang kemudian disebut dengan proses akomodasi.

Pendapat Piaget tentang bagaimana sebenarnya pengetahuan itu terbentuk dalam struktur kognitif anak, sangat berpengaruh terhadap beberapa model pembelajaran, diantaranya model pembelajaran kontekstual.. menurut pembelajaran kontekstual, pengetahuan itu akan bermakna manakala ditemukan dan dibangun sendiri oleh siswa.

\section{Latar belakang Psikologis}

Dipandang dari sudut psikologis, CTL berpijak pada aliran psikologis kognitif. Menurut aliran ini proses belajar terjadi karena pemahaman individu akan lingkungan. Belajar bukanlah peristiwa mekanis seperti keterkaitan stimulus dan respon. Belajar melibatkan proses 
mental yang tidak tampak seperti emosi, minat, motivasi, dan kemampuan atau pengalaman.

Ada yang perlu dipahami tentang pembelajar dalam konteks CTL.

1. Belajar bukanlah menghafal, akan tetapi proses mengkontruksi pengetahuan sesuai dengan pengalaman yang mereka miliki

2. Belajar bukan sekedar mengumnpulkan fakta yang lepas-lepas.

3. Belajar adalah proses pemecahan masalah

4. Belajar adalah proses pengalaman sendiri yang berkembang dari yang sederhana menuju yang kompleks

5. Belajar pada hakikatnya adalah menangkap pengetahuan dari kenyataan.

\section{Perbedaan CTL dengan Pembelajaran Konvensioanal}

\begin{tabular}{|c|c|c|}
\hline \multirow[t]{2}{*}{ No. } & \multicolumn{2}{|c|}{$\begin{array}{c}\text { Perbedaan CTL dengan Pembelajaran } \\
\text { Konvensioanal }\end{array}$} \\
\hline & $C T L$ & $\begin{array}{l}\text { Pembelajaran } \\
\text { Konvensional }\end{array}$ \\
\hline 1 & $\begin{array}{l}\text { Siswa sebagai subjek } \\
\text { belajar }\end{array}$ & $\begin{array}{l}\text { Siswa sebagai } \\
\text { objek belajar }\end{array}$ \\
\hline 2. & $\begin{array}{l}\text { Siswa belajar melalui } \\
\text { kegiatan kelompok }\end{array}$ & $\begin{array}{l}\text { Siswa lebih banyak } \\
\text { belajar } \\
\text { indidu }\end{array}$ \\
\hline 3. & $\begin{array}{l}\text { Pembelajaran } \\
\text { dikaitkan dengan } \\
\text { kehidupan nyata }\end{array}$ & $\begin{array}{l}\text { Pembelajaran } \\
\text { bersifat teoritis dan } \\
\text { abstrak }\end{array}$ \\
\hline 4 & $\begin{array}{l}\text { Kemampuan } \\
\text { didasarkan } \\
\text { pengalaman }\end{array}$ & $\begin{array}{l}\text { Kemampuan } \\
\text { diperoleh dari } \\
\text { latihan-latihan }\end{array}$ \\
\hline 5 & $\begin{array}{ll}\text { Tujuan akhir } \\
\text { kepuasan diri }\end{array}$ & $\begin{array}{l}\text { Tujuan akhir nilai } \\
\text { atau angka }\end{array}$ \\
\hline 6 & $\begin{array}{l}\text { Prilaku dibangun atas } \\
\text { kesadaran }\end{array}$ & $\begin{array}{l}\text { Prilaku dibangun } \\
\text { oleh factor dari luar }\end{array}$ \\
\hline 7 & 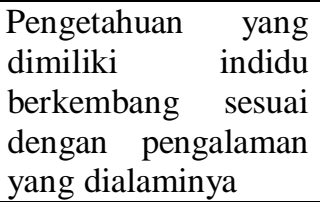 & $\begin{array}{l}\text { Pengetahuan yang } \\
\text { dimiliki bersifat } \\
\text { absolute dan final, } \\
\text { tidak mungkin } \\
\text { berkembang. }\end{array}$ \\
\hline 8 & $\begin{array}{l}\text { Siswa } \\
\text { bertanggungjawab } \\
\text { dalam memonitor } \\
\text { dan mengembangkan } \\
\text { pembelajaran }\end{array}$ & $\begin{array}{lr}\text { Guru penentu } \\
\text { jalannya proses } \\
\text { pembelajaran }\end{array}$ \\
\hline 9 & $\begin{array}{l}\text { Pembelajaran bisa } \\
\text { terjadi dimana saja }\end{array}$ & $\begin{array}{l}\text { Pembelajaran } \\
\text { terjadi hanya di } \\
\text { dalam kelas }\end{array}$ \\
\hline 10 & $\begin{array}{l}\text { Keberhasilan } \\
\text { pembelajaran dapat } \\
\text { diukur dengan } \\
\text { berbagai cara }\end{array}$ & $\begin{array}{l}\text { Keberhasilan } \\
\text { pembelajaran } \\
\text { hanya bisa diukur } \\
\text { dengan tes }\end{array}$ \\
\hline
\end{tabular}

\section{METODE}

Penelitian ini menggunakan Rancangan Penelitian Tindakan Kelas yang berfokus dalam kegiatan siswa dalam pembelajaran

1. Tempat penelitian ini dilakukan di SD Sumur 03 Kelas IV Kecamatan Cluwak, Kabupaten Pati Tahun Pelajaran 2016/2017. Hal ini disebabkan karena keterbatasan pemikiran, biaya, dan tenaga selain itu peneliti adalah guru di SD Negeri Sumur 03 oleh sebab itu peneliti memilih setting penelitian ini dilaksanakan di SD Negeri Sumur 03

2. Banyaknya siswa yang menikuti 18 orang siswa terdiri dari 10 siswa laki-laki dan 8 siswa perempuan

3. Kegiatan penelitian ini dilaksanakan pada semester I tahun pelajaran 2016/2017.

4. Dalam pelaksanaan tindakan, rancangan dilakukan dalam 3 siklus yang meliputi: (a) perencanaan, (b) tindakan, (c) pengamatan, (d) refleksi.

\section{HASIL DAN PEMBAHASAN}

Penelitian ini peneliti lakukan di sekolah dasar tempat peneliti mengajar yaitu di SD Negeri Sumur 03 Kecamatan Cluwak, Kabupaten Pati, pada tahun pelajaran 2016/2017. Ini peneliti sebagai Guru Kelas mengajar di kelas IV. Jumlah siswa 18 orang terdiri dari laki-laki 10 orang dan perempuan 8 orang. Pada kondisi awal pembelajaran siswa memperoleh nilai yang kurang memenuhi harapan beberapa siswa memperoleh nilai minimal 65 sesuai yang telah ditetapkan KKM. Hasil penelitian menunjukkan bahwa pada kondisi awal 18 siswa, sebanyak 8 siswa (65\%) belum tuntas dan 10 siswa (35\%) mempunyai kemampuan awal yang mendapat nilai lebih dari 65 (dikatakan tuntas), sedangkan pada pra siklus yang peneliti lakukan pada hari Senin dan Selasa tanggal 8-9 September 2016, dengan memberikan soal tentang operasi hitung pecahan dalam pemecahan masalah pada kelas IV dengan pendekatan CTL. Hasil yang diperoh mencapai $35 \%$ tuntas atau 8 siswa memperoleh nilai diatas KKM, sedangkan yang belum mencapai KKM sebanayak 10 siswa dapat dikatakan (35\%) tidak tuntas. Penelitian siklus I dilaksanakan Senin dan Selasa tanggal 15-16 September 2016. Dengan memberikan soal tentang Melakukan operasi hitung pecahan dalam pemecahan masalah di kelas IV dengan pendekatan CTL. Hasil yang diperoleh mencapai $100 \%$ tuntas atau 18 siswa memperoleh nilai diatas KKM.

Pada akhir siklus I peneliti memberi soal tentang Melakukan operasi hitung pecahan dalam pemecahan masalah kepada siswa 
sebanyak 10 soal isian, yang berkaitan dengan Melakukan operasi hitung pecahan dalam pemecahan masalah. Waktu untuk menyelesaikan selama 30 menit kemudian siswa diperintahkan untuk mencocokkan dengan langkah yang di berikan guru.

Keberhasilan sebelum dilaksanakan pra siklus (pre tes) dengan rata-rata 60,3 pada akhir siklus I prestasi belajar mencapai rata-rata 71,8. Kesalahan dalam mengejakan soal cukup beragam diketahui pada sebelum siklus dari tes awal dan tes akhir siklus I yaitu : (1) kesalahan memahami maksud soal sebanyak 4 siswa, (2) kesalahan dalam mengoperasikan soal yang diharapkan sebanyak 7 siswa, (3) kesalahan dalam menentukan hasik akhir sebanyak 5 siswa.

Dengan demikian siklus I keberhasilan mencapai $80 \%$ dengan keberhasilan yang demikian, belum memenuhi apa apa yang diharapkan, maka peneliti mengadakan refleksi ulangan terhadap terhadap perencanaan siklus I. Hal-hal yang dilakukan peneliti : (1) Memperbaiki perencanaan siklus I untuk ditingkatkan pada siklus II, (2) memberikan contoh-contoh soal yang lebih jelas dan dimengerti siswa, (3) Mengadakan cek hasil pengamatan guru terhadap peneliti, atas kekurangan-kekurangan dalam pembelajaran siklus I

Pada akhir siklus II merupakan usaha memperbaiki pembelajaran terhadap siklus I yang dianggap ada sebagian anak yang belum tuntas belajarnya, peneliti memberikan 5 soal cerita yang berkaitan dengan Melakukan operasi hitung pecahan dalam pemecahan masalah. Waktu untuk menyelesaikan 30 menit kemudian siswa diperintahkan untuk mencocokkan dengan langkah yang diberikan guru.

Peningkatan belajar siswa pada pra siklus dari rata-rata 60,3 menjadi 71,8 pada siklus I dengan rincian : ada 5 siswa yang mendapat nilai 65 dikatakan berhasil dan 13 siswa mendapat nilai diatas 65. Akhir siklus II dikatakan berhasil karena ada 18 siswa seluruhnya telah mengalami peningkatan hasil belajar dan pada akhir siklus II semua (100\%) tuntas. Sedangkan hasil observasi guru dalam pembelajaran juga mengalami peningkatan yang berarti bahwa guru telah menggunakan langkahlangkah dengan pendekatan CTL dengan baik.

Keberhasilan tersebut diketahui dari pemahaman terhadap apa yang diminta soal dapat dipahami dan dimengerti siswa, proses Melakukan operasi hitung pecahan dalam pemecahan masalah dengan benar dikerjakan, soal dikerjakan dengan tepat dan hasil akhir juga benar. Kemampuan siswa dalam menyelesaikan masalah pada materi Melakukan operasi hitung pecahan dalam pemecahan masalah di kelas IV dianggap meningkat dengan pendekatan CTL. Dalam pembelajaran yang menggunakan pendekatan CTL sikap siswa dalam pembelajaran menunjukkan adanya antusias yang baik untuk mengikuti pembelajaran matematika.

Apa yang dilaksanakan dalam penelitian tindakan kelas ini telah mampu meningkatkan hasil belajar siswa dalam menyelesaikan soal Melakukan operasi hitung pecahan dalam pemecahan masalah dengan menggunakan model CTL.

Pembelajaran dengan mengimplikasikan pendekatan CTL dalam penelitian ditemukan bahwa guru harus mampu membuat realisasi dari hal-hal yang abstrak menjadi nyata sehingga cepat ditangkap siswa, jika bersifat kata-kata, guru perlu memberikan dengan disertai gambargambar, model-model dan cara pengerjaan yang terlebih dahulu dengan menggunakan LKS yang dikerjakan siswa secara kelopok-kelompok kecil dengan tujuan agar siswa yang kurang cepat diterima oleh sebagian siswa dapat dibantu oleh teman sekelompoknya yang telah menguasai materi Melakukan operasi hitung pecahan dalam pemecahan masalah tersebut. Dengan bimbingan guru untuk mengerjakan soal siswa dapat menyelesaikannya dengan lebih baik.

Bimbingan guru dalam melatih siswa terutama yang kurang minat terhadap matematika sangat berperan. Apabila siswa telah terlatih maka model Melakukan operasi hitung pecahan dalam pemecahan masalah apa saja akan mudah diselesaikan siswa karena pada dasarnya pendekatan CTL ini adalah suatu pendekatan yang berbasis masalah yang selalu akrab dengan lingkungan siswa. Pendekatan untuk membuat konsep abstrak menjadi lebih nyata dengan mengimplementasikan pemberdayaan alat peraga sehingga mudah dicerna dan dimengerti siswa, pelaksanaan proses pembelajaran mempunyai peranan penting untuk tercapainya keberhasilan pembelajaran. Dengan terlaksananya penelitian tindakan kelas ini, maka hasil belajar siswa meningkat tinggi, sehingga mencapai hasil tuntas sesuai dengan kompetensi dasar yang telah ditentukan. 
Tabel 1. Analisas Nilai Hasil Tes Akhir Dalam Proses Perbaikan Pembelajaran

\begin{tabular}{|c|c|c|c|c|c|c|c|c|c|c|}
\hline \multirow{3}{*}{$\begin{array}{l}\mathrm{N} \\
\mathrm{O}\end{array}$} & \multirow{3}{*}{ Nama Siswa } & \multicolumn{9}{|c|}{ Analisis Hasil Evaluasi } \\
\hline & & \multicolumn{3}{|c|}{ Pra Siklus } & \multicolumn{3}{|c|}{ Siklus I } & \multicolumn{3}{|c|}{ Siklus II } \\
\hline & & $\mathrm{N}$ & $\mathrm{T}$ & BT & $\mathrm{N}$ & $\mathrm{T}$ & BT & $\mathrm{N}$ & $\mathrm{T}$ & BT \\
\hline 1 & Rifki Andriyansah & 70 & $\sqrt{ }$ & - & 75 & $\sqrt{ }$ & - & 100 & $\sqrt{ }$ & - \\
\hline 2 & Maulana F.R & 55 & - & $\sqrt{ }$ & 65 & $\sqrt{ }$ & - & 65 & $\sqrt{ }$ & - \\
\hline 3 & Ahmad Zaki Romadhon & 65 & $\sqrt{ }$ & - & 65 & $\sqrt{ }$ & & 65 & $\sqrt{ }$ & - \\
\hline 4 & Atry Rhesyia & 60 & - & $\sqrt{ }$ & 70 & $\sqrt{ }$ & - & 70 & $\sqrt{ }$ & - \\
\hline 5 & Beti Nur Sabrina & 50 & - & $\sqrt{ }$ & 55 & - & $\sqrt{ }$ & 75 & $\sqrt{ }$ & - \\
\hline 6 & Dela Darista & 55 & - & $\sqrt{ }$ & 75 & $\sqrt{ }$ & - & 85 & $\sqrt{ }$ & - \\
\hline 7 & Diana Fata Sari & 65 & $\sqrt{ }$ & - & 75 & $\sqrt{ }$ & - & 75 & $\sqrt{ }$ & - \\
\hline 8 & Dino Cahyono & 55 & - & $\sqrt{ }$ & 60 & $\sqrt{ }$ & - & 75 & $\sqrt{ }$ & - \\
\hline 9 & Etna Tur Candika & 55 & - & $\sqrt{ }$ & 75 & $\sqrt{ }$ & - & 85 & $\sqrt{ }$ & - \\
\hline 10 & Etna Rona Hidayah & 80 & $\sqrt{ }$ & - & 80 & $\sqrt{ }$ & - & 100 & $\sqrt{ }$ & - \\
\hline 11 & Fadliratul Maulinda & 80 & $\sqrt{ }$ & - & 80 & $\sqrt{ }$ & - & 100 & $\sqrt{ }$ & - \\
\hline 12 & Hestia Nur Rizka Mulyadi & 55 & - & $\sqrt{ }$ & 60 & - & $\sqrt{ }$ & 70 & $\sqrt{ }$ & - \\
\hline 13 & Muhammad Arif F & 65 & $\sqrt{ }$ & - & 75 & $\sqrt{ }$ & - & 75 & $\sqrt{ }$ & - \\
\hline 14 & Muhammad Amanda F & 45 & - & $\sqrt{ }$ & 50 & - & $\sqrt{ }$ & 70 & $\sqrt{ }$ & - \\
\hline 15 & Muhammad Mahfud Efendi & 65 & $\sqrt{ }$ & - & 65 & $\sqrt{ }$ & - & 75 & $\sqrt{ }$ & - \\
\hline 16 & Riyan Choirul Majid & 60 & - & $\sqrt{ }$ & 60 & - & $\sqrt{ }$ & 80 & $\sqrt{ }$ & - \\
\hline 17 & Sya`rotul Sita Liyana & 50 & - & $\sqrt{ }$ & 55 & - & $\sqrt{ }$ & 75 & $\sqrt{ }$ & - \\
\hline 18 & Muhammad Erlangga A & 65 & $\sqrt{ }$ & - & 75 & $\sqrt{ }$ & - & 90 & $\sqrt{ }$ & - \\
\hline
\end{tabular}

Tabel 2. Hasil observasi terhadap 18 siswa dalam menyelesaikan soal tentang Melakukan operasi hitung pecahan dalam pemecahan masalah di kelas IV SD Negeri Sumur 03

\begin{tabular}{|c|c|c|c|c|}
\hline No & Aspek Kesalahan yang diamati & Banyak siswa & $\%$ & Keterangan \\
\hline 1 & $\begin{array}{l}\text { Kurang paham apa yang ditanyakan oleh soal } \\
\text { Melakukan operasi hitung pecahan dalam } \\
\text { pemecahan masalah }\end{array}$ & 3 & 16,6 & \multirow{4}{*}{$\begin{array}{l}\text { Ada } 12(40 \%) \text { siswa } \\
\text { yang } \quad \text { dianggap } \\
\text { memiliki kemampuan } \\
\text { tinggi r dalam } \\
\text { menyelesaikan soal }\end{array}$} \\
\hline 2 & $\begin{array}{l}\text { Paham apa yang ditanyakan tetapi kurang } \\
\text { mampu mengopresikan yang diharapkan oleh } \\
\text { soal }\end{array}$ & 2 & 11,1 & \\
\hline 3 & Keliru dalam menentukan hasi akhir & 1 & 5,6 & \\
\hline 4 & $\begin{array}{l}\text { Telah berhasil/mampu menyelesaikan masalah } \\
\text { dalam Melakukan operasi hitung pecahan } \\
\text { dalam pemecahan masalah }\end{array}$ & 12 & 66,6 & \\
\hline
\end{tabular}

Tabel 3 Rekapitulasi hasil belajar siswa

\begin{tabular}{|c|c|c|c|c|c|c|}
\hline \multirow{2}{*}{ Hasil Belajar } & \multicolumn{2}{|c|}{ Pra Siklus } & \multicolumn{2}{|c|}{ Siklus I } & \multicolumn{2}{|c|}{ Siklus II } \\
\hline & Jumlah & $\begin{array}{c}\text { Persen } \\
\text { tase }\end{array}$ & Jumlh & $\begin{array}{c}\text { Persen } \\
\text { tase }\end{array}$ & Jumlh & $\begin{array}{c}\text { Persen } \\
\text { tase }\end{array}$ \\
\hline Skor $<65$ & 10 & $56 \%$ & 4 & $23 \%$ & 0 & $0 \%$ \\
\hline Skor $\geq 65$ & 8 & $44 \%$ & 12 & $67 \%$ & 18 & $100 \%$ \\
\hline Tuntas belajar & 8 & $44 \%$ & 12 & $67 \%$ & 18 & $100 \%$ \\
\hline Tidak tuntas belajar & 10 & $56 \%$ & 4 & $23 \%$ & 0 & $0 \%$ \\
\hline Nilai rata-rata & \multicolumn{2}{|c|}{60,3} & \multicolumn{2}{|c|}{68,3} & \multicolumn{2}{|c|}{80} \\
\hline
\end{tabular}


Tabel 4 Data motivasi Siswa Dalam Pembelajaran Kelompok

\begin{tabular}{|c|l|c|c|c|c|}
\hline \multirow{2}{*}{ No Indikator } & \multicolumn{2}{c|}{ Siklus I } & \multicolumn{2}{c|}{ Siklus II } \\
\cline { 3 - 5 } & & Hasil & Presentase & Hasil & Presentase \\
\hline 1 & Tingkat keinginan anggota dalam kelompok & 3 & 60 & 4 & 80 \\
\hline 2 & Kekompakan kerja kelompok & 3 & 60 & 4 & 80 \\
\hline 3 & Tingkat heterogenitas kelompok & 3 & 60 & 3 & 60 \\
\hline 4 & $\begin{array}{l}\text { Kemampuan kelompok dalam } \\
\text { menyelesaikan tugas }\end{array}$ & 3 & 60 & 4 & 80 \\
\hline 5 & Kesan umun cara pembentukan kelompok & 3 & 60 & 3 & 60 \\
\hline & Rata-rata & 3 & 60 & 3,6 & 76 \\
\hline
\end{tabular}

Tabel 5 Hasil Observasi Performasi Guru dalam Pembelajaran dengan alat Peraga Pengukuran Kompetensi Guru (APKG)

\begin{tabular}{|c|l|c|c|}
\hline No & \multicolumn{1}{|c|}{ Aspek yang diamati } & $\begin{array}{c}\text { Nilai } \\
\text { performasi } \\
\text { Siklus I }\end{array}$ & $\begin{array}{c}\text { Nilai } \\
\text { performasi } \\
\text { Siklus II }\end{array}$ \\
\hline 1 & Mengelola ruang dan fasilitas pembelajaran & 3 & 4 \\
\hline 2 & Melaksanakan kegiatan pembelajaran & 3 & 4 \\
\hline 3 & Mengelola interaksi kelas & 3 & 3 \\
\hline 4 & $\begin{array}{l}\text { Bersifat terbuka dan luwes serta membantu mengembangkan sikap } \\
\text { positif siswa terhadap belajar }\end{array}$ & 4 & 4 \\
\hline 5 & Mendemontrasikan kemampuan mata pelajaran matematika & 4 & 4 \\
\hline 6 & Melaksanakan evaluasi proses dan hasil belajar & 4 & 4 \\
\hline 7 & Kesan umum kinerja guru & 3 & 4 \\
\hline Skor rata-rata & 3,42 & 3,85 \\
\hline
\end{tabular}

\section{PEMBAHASAN}

Pra Siklus

Dalam pembelajaran ini dapat dikatakan unik Oleh karena itu, pada penelitian tindakan kelas seklus I peneliti memberikan tehnik penyelesaian soal tentang Melakukan operasi hitung pecahan dalam pemecahan masalah melalui pendekatan Teaching and Learning (CTL). Pelaksanaan tindakan siklus I tersebut langkah-langkah yang dilakukan pada pembelajaran adalah sebagai berikut: (1) guru menyiapkan bahan ajar dengan pokok bahasan Melakukan operasi hitung pecahan dalam pemecahan masalah dengan menggunakan pendekatan Teaching and Learning (CTL)., (2) menjelaskan materi dan menyuruh siswa menyebutkan benda-benda yang ada hubungannya tentang Melakukan operasi hitung pecahan dalam pemecahan masalah yang ada dilingkungan siswa, (3) membentuk kelompok secara acak dengan memperhatikan setiap kelompok ada siswa yang pandai dan kurang pandai. Siswa yang pandai berlaku tutor sebaya, (4) siswa menyelesaikan tugas-tugas yang diberikan Guru bersama kelompoknya yang dipimpin tutor sebaya sebagai ketua kelompok, (5) guru mengamati jalannya kerjasama dalam kelompok, (6) guru membahas tugas yang diselesaikan secara bersama. dengan pemberian soal untuk diselesaikan siswa secara individu. Setelah dilaksanakan secara individu kemudian tugas cecara kelompok. Setelah pembahasan soal dilanjutkan dengan pos tes. Titik perhatian dalam siklus I adalah agar siswa memahami apa yang ditanyakan dan bagaimana cara operasionalnya sehingga anak mengerti apa yang ditanyakan dan bagaimana yang dikehendaki. Pemahaman siswa diharapkan akan tumbuh dalam siklus I sehingga akan memudahkan untuk menyelesaikan soal yang diberikan oleh guru.

\section{Siklus I}

Menurut penelitian pelaksanaan siklus I sudah ada peningkatan yang signifikan karena perolehan nilai pada siklus I, ada 13 siswa yang mendapat nilai 65 atau lebih, sedangkan pada siklus II ada 18 siswa semua tuntas.

Dari data tabel diatas rata-rata motifasi siswa dalam pembelajaran kelompok pada siklus I adalah 3 ( $60 \%$ ) dengan kategori baik (B). Sedangkan pada siklus II rata-rata keberhasilan siswa mengalami peningkatan yaitu 3,60 ( 76\%) dengan kategori baik sekali (BS). Motivasi siswa dalam pembelajaran klasikal dapat diketahui yaitu rata-rata siklus I adalah $3(60 \%)$ dengan kategori baik (B). Sedangkan pada siklus II rata- 
rata motivasi siswa mengalami peningkatan yaitu 3,60 (76\%) dengan kategori baik sekali (BS) yang berarti bahwa pada siklus II dalam pembelajaran kelompok $76 \%$ pada siklus II pembelajaran klasikal. Hasil observasi guru dalam pembelajaran dengan pendekatan Teaching and Learning (CTL). Sehingga hasil perbaikan pembelajaran sangat memuaskan dan bisa mencapai tujuan pembelajaran yang telah dirancang sebelumnya.

\section{Siklus II}

Pada akhir siklus II merupakan usaha memperbaiki pembelajaran terhadap siklus I yang dianggap ada sebagian anak yang belum tuntas belajarnya.

Keberhasilan tersebut diketahui dari pemahaman terhadap apa yang diminta soal dapat dipahami dan dimengerti siswa, proses Melakukan operasi hitung pecahan dalam pemecahan masalah dengan benar dikerjakan, soal dikerjakan dengan tepat dan hasil akhir juga benar. Kemampuan siswa dalam menyelesaikan masalah pada materi Melakukan operasi hitung pecahan dalam pemecahan masalah di kelas IV dianggap meningkat dengan Teaching and Learning (CTL). Dalam pembelajaran yang menggunakan pendekatan Teaching and Learning (CTL) sikap siswa dalam pembelajaran menunjukkan adanya antusias yang baik untuk mengikuti pembelajaran matematika.

Dari kegiatan refleksi, diketahui bahwa kekurangan siwa pada Melakukan operasi hitung pecahan dalam pemecahan masalah adalah yang berkaitan dengan soal cerita karena butuh penalaran dan ketelitian oleh sebab itu perlu dikaji kembali dengan menggunkaan alat peraga melalui pendekatan Teaching and Learning (CTL), diharapkan lebih dapat dimengerti siswa. Dengan menggunakan pendekatan Teaching and Learning (CTL) dan banyak melatih siswa akan memudahkan siswa dalam pemahaman memecahkan masalah Melakukan operasi hitung pecahan dalam pemecahan masalah. Kegiatan guru pada saat siswa mengerjakan soal diharapkan menjadi fasilitator sehingga dimana ada siswa yang mengalami kesulitan belajar diharapkan guru memberikan penjelasan. Senada yang dikemukakan oleh Sujana (1998:100) bahwa alat bantu yang berupa alat peraga dalam proses pembelajaran dapat :

a. Meningkatkan minat dan perhatian siswa terhadap pembelajaran

b. Meletakkan dasar dasar yang nyata untuk berfikir (menghilangkan ferbalisme)

c. Meletakkan dasar perkembangan belajar, sehingga hasil belajat lebih mantap

d. Memberikan pengalaman yang nyata e. Menumbuhkan pemikiran yang teratur dan berkesinambungan

f. Memberikan pengalaman yang sempurna

g. Membantu tumbuhnya pemikiran dan perkembangan kemampuan berbahasa

Setelah melaksanakan perbaikan proses pembelajaran pada siklus II dengan mengoptimalkan pengunaan alat peraga dan media pembelajaran yang sesuai dengan karakteristik lingkungan siswa ternyata hasil pembelajaran sengat memuaskan yaitu nilai ketuntasan secara klasikal yang tercapai pada siklus I hanya $68,3 \%$ ternyata pada siklus II bisa mencapai $80 \%$.

\section{SIMPULAN}

Setelah melakukan penelitian perbaikan pembelajaran dari pra siklus, siklus I dan II hingga selesai, menganalisis hasil observasi, hasil tes formatif dan merekap perolehan nilai siswa pada pembelajaran Matematika materi ajar tentang Melakukan operasi hitung pecahan dalam pemecahan masalah dengan pendekatan Teaching and Learning (CTL) dapat ditarik kesimpulan sebagai berikut :

1. Dengan menggunakan pendekatan Teaching and Learning (CTL) dapat meningkatkan aktifitas belajar Melakukan operasi hitung pecahan dalam pemecahan masalah pada siswa kelas IV semester I tahun pelajaran 2016/2017 di SD Negeri Sumur 03 Kecamatan Cluwak, Kabupaten Pati

2. Dengan menggunakan pendekatan Teaching and Learning (CTL) dapat meningkatkan hasil belajar materi operasi hitung pecahan dalam pemecahan masalah pada siswa kelas IV semester I tahun pelajaran 2016/2017 di SD Negeri Sumur 03 Kecamatan Cluwak, Kabupaten Pati

3. Dalam pembelajaran dengan menggunakan Penelitian Tindakan Kelas yang dilaksanakan secara berkala dan terprogram dapat mengembangkan professional guru secara terarah dan inovatif.

\section{DAFTAR PUSTAKA}

Aburahman, Mulyono. 2001. Pendidikan Bagi Anak Berkesulitan Belajar. Jakarta : PT Rineka Cipta dan Depdikbud

Arikunto Suharsimi., Suharjono, Supardi. 2008. Penelitian Tindakan Kelas Jakarta :Sinar Grafika

Gravemeijer, K. 1994. Develomping Realistic Mathematics Education. Freudenthal Institute. Nederlands 
Hamalik, Oemar. 2008. Proses Belajar Mengajar dan Kurikulum dan Pembelajaran. Jakarta : Sinar Grafik

Rohani, Ahmad. 2004. Pengelolaan Pembelajaran. Jakarta: Rineka Cipta.

R. Soedjadi. 2000. Kiat Pendidikan Matematika di Indonesia, Jakarta: Direktorat Jendral Pendidikan Nasional.

Slameto. 1995. Belajar dan Faktor-Faktor yang Mempengaruhinya. Jakarta : Rineka Cipta

Soemanto, Wasty. 2006. Psikologi Pendidikan. Jakarta: Rineka Cipta.

Sudjana, Nana. 2010. Penilaian Hasil Proses Belajar Mengajar. Bandung: PT. Ramaja Rosdakarya.

Sumanto.YD, Kusumawati Heny, Aksi Nur. 2007. Gemar Matematika. Jakarta : Pusat Perbukuan Departemen pendidikan

Usman, Moh Uzer dan Lilis Setiawati. 2001. Upaya Optimalisasi Kegiatan Belajar Mengajar. Bandung: Remaja Rosdakarya. 